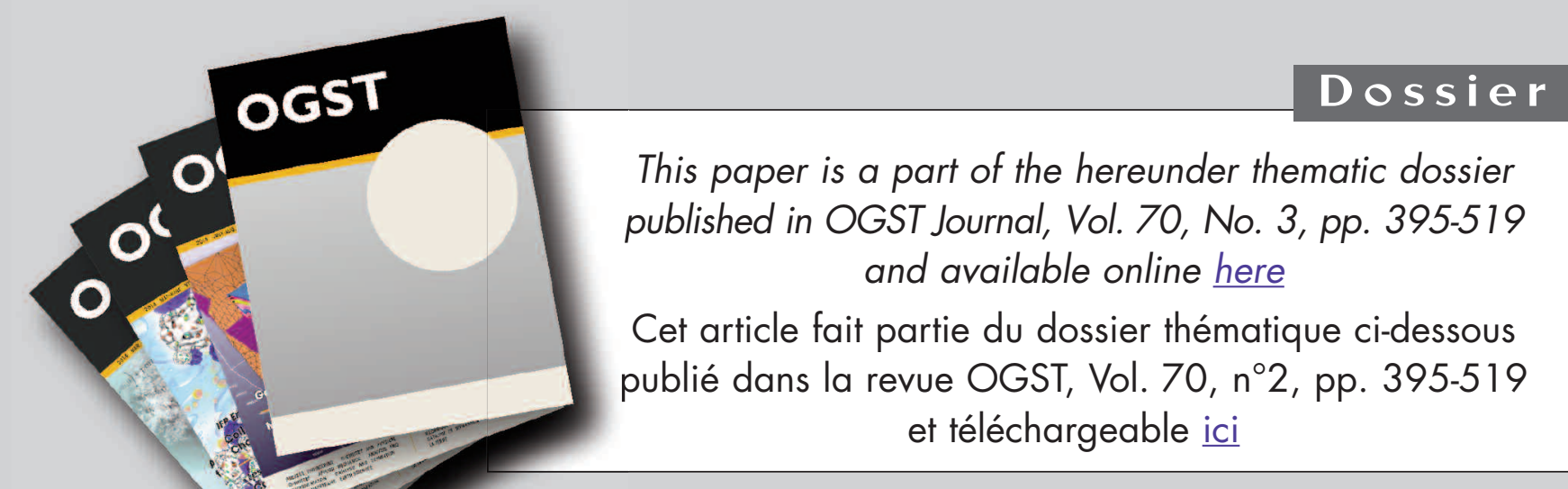

DOSSIER Edited by/Sous la direction de : V. Santos-Moreau

IFP Energies nouvelles International Conference / Les Rencontres Scientifiques d'IFP Energies nouvelles NEXTLAB 2014 - Advances in Innovative Experimental Methodology or Simulation Tools used to Create, Test, Control and Analyse Systems, Materials and Molecules

NEXTLAB 2014 - Innover dans le domaine de la méthodologie expérimentale et des outils de simulation pour créer, tester, contrôler et analyser des systèmes, matériaux et molécules

Oil \& Gas Science and Technology - Rev. IFP Energies nouvelles, Vol. 70 (2015), No. 3, pp. 395-519

Copyright (C) 2015, IFP Energies nouvelles

$395>$ Editorial - Towards the Laboratory of the Future for the Factory of the Future Éditorial - Vers le laboratoire du futur pour construire l'usine du futur V. Santos-Moreau, J.M. Newsam and J.-C. Charpentier

$405>$ Automatic and Systematic Atomistic Simulations in the MedeA ${ }^{\circledR}$ Software Environment: Application to EU-REACH

Simulations atomistiques automatiques et systématiques dans l'environnement logiciel de MedeA® : application à EU-REACH

$X$. Rozanska, P. Ungerer, B. Leblanc, P. Saxe and E. Wimmer

419 > Development of an Innovative XRD-DRIFTS Prototype Allowing Operando Characterizations during Fischer-Tropsch Synthesis over Cobalt-Based Catalysts under Representative Conditions

Développement d'un prototype DRX-DRIFTS innovant permettant des caractérisations operando de catalyseurs à base de cobalt pendant la synthèse de Fischer-Tropsch en conditions représentatives

J. Scalbert, I. Clémençon, C. Legens, F. Diehl, D. Decottignies and S. Maury

429 > Synchrotron X-ray Scattering as a Tool for Characterising Catalysts on Multiple Length Scales

La diffusion des rayons $X$ synchrotron : un outil pour la caractérisation des catalyseurs sur les multiples échelles de longueur

J.M. Hudspeth, K.O. Kvashnina, S.A.J. Kimber and E.P. Mitchell

437 > High Throughput Experimentation (HTE) Directed to the Discovery,

Characterization and Evaluation of Materials

Expérimentation à haut débit pour la découverte, la caractérisation et

l'évaluation des matériaux

J.M. Newsam

447 > The Use of Original Structure-Directing Agents for the Synthesis of EMC-1 Zeolite L'utilisation d'agents structuraux originaux pour la synthèse de zéolithe EMC-1

T.J. Daou, J. Dhainaut, A. Chappaz, N. Bats, B. Harbuzaru, H. Chaumeil, A. Defoin,

L. Rouleau and J. Patarin
455 > REALCAT: A new Platform to Bring Catalysis to the Lightspeed REALCAT : une nouvelle plate-forme pour mener la catalyse à la vitesse de la lumière

S. Paul, S. Heyte, B. Katryniok, C. Garcia-Sancho, P. Maireles-Torres and F. Dumeignil

$463>$ What are the Needs for Process Intensification? Quels besoins pour intensifi er un procédé ?

C. Gourdon, S. Elgue and L. Prat

$475>$ Revisiting the Side Crushing Test Using the Three-Point Bending Test for the Strength Measurement of Catalyst Supports

Test d'écrasement grain à grain revisité à l'aide du test de flexion trois points pour la mesure de la résistance des supports de catalyseurs D. Staub, S. Meille, V. Le Corre, J. Chevalier and L. Rouleau

487 > Refractometric Sensing of Heavy Oils in Fluorescent Core Microcapillaries La détection réfractométrique des huiles lourdes dans les microcapillaires à cœur fluorescents

V. Zamora, Z. Zhang and A. Meldrum

497 > Two-Phase Flow in Pipes: Numerical Improvements and Qualitative Analysis for a Refining Process

Écoulements diphasiques dans les conduites : améliorations numériques et analyse qualitative pour un procédé de raffinage

R.G.D. Teixeira, A.R. Secchi and E.C. Biscaia Jr

511 > Comparative TPR and TPD Studies of Cu and Ca Promotion on Fe-Zn- and Fe-Zn-Zr-Based Fischer-Tropsch Catalysts

Études comparatives par TPR et TPD de la promotion par Cu et Ca de I'activité de catalyseurs Fischer-Tropsch Fe-Zn et Fe-Zn-Zr 0.0 . James, B. Chowdhury and S. Maity 


\title{
Editorial
}

\section{TOWARDS THE LABORATORY OF THE FUTURE FOR THE FACTORY OF THE FUTURE}

\author{
V. Santos-Moreau', J.M. Newsam ${ }^{2}$ and J.-C. Charpentier ${ }^{3}$ \\ ${ }^{1}$ IFP Energies nouvelles, France \\ 2 TIOGA Research, USA \\ ${ }^{3}$ LRGP/CNRS/ENSIC, Université de Lorraine, France
}

As a scientific community concerned about energy, resources utilization and environmental problems, chemical and petrochemical conversions, and other related issues, we are at the vanguard of research challenges of major societal impact. No longer have we the luxury of being motivated by simple curiosity or competition. Our timelines are instead pressured by the pace of global changes, sustainability and requirements for technological innovation. But, when presented with an urgent, yet well described research and development need, how can we be more efficient, more effective, and ultimately more successful? Addressing that question was the theme of the NextLab 2014 conference that brought together leading scientists and engineers from 14 countries at the IFP Energies nouvelles (IFPEN) facilities in Rueil-Malmaison near Paris (France) on April 2-4 2014.

In his opening address, Eric Heintzé, IFPEN's Scientific Director, articulated the goal of the NextLab 2014 conference, as being "to bring together different actors, academic players and industrialists, in order to share experiences and visions, around the topic of the laboratory of the future supporting innovation". He anticipated presentations and "constructive debates" on "cutting-edge tools, methodologies and techniques from the laboratory to the pilot, and up to the process scale, in order to improve knowledge and scientific progress and to support innovation activities for products and processes".

The conference was then deliberately structured so as to focus attention, in a measured progression, on key phases in Research, Development and Deployment (RDD), each emphasizing approaches to innovation.

Session 1 considered "New Experimental and Simulation Tools for Material Design, Synthesis and Formulation".

This session emphasized, first, the use of molecular modeling and in silico experiments for understanding fundamental phenomena and for assessing physical properties otherwise unavailable such as mass and heat transport, mechanical or redox properties. A paper by X. Rozanska, P. Ungerer, B. Leblanc, P. Saxe and E. Wimmer entitled "Automatic and Systematic Atomistic Simulations in the MedeA ${ }^{\circledR}$ Software Environment: Application to EU-REACH" describing atomistic simulations to determine missing physical-chemical properties of substances in the context of EU-REACH regulation, is presented in this OGST dossier.

Second, this session considered approaches to produce new experimental data beyond the possibilities of current experimental technologies such as the use of High Throughput Synthesis (HTS) of molecules as solvents, or other materials for a given industrial application. 
A key question was "are nowadays' in silico molecular experiments fully suitable as a basis for the design of products and processes?'. The answer was clearly still 'No'. The laboratory of the future will necessarily combine complementary real and virtual experiments for a more efficient and safe design of processes and products, using a multi-scale approach.

Session 2 considered "Innovative Tools and Methods to Evaluate and Characterize Materials".

The session highlighted the use of microfluidics, unconventional millifluidic tools and, more generally, innovative tools to sustain chemical and process development, and gain basic kinetic data for chemical processes. This theme was illustrated by the use of in situ thermographic and infra-red tools for catalyst characterization during reactions. The former comprised an in situ spatially resolved observation of features within a catalyst under reaction conditions. The latter, in operando X-Ray Diffraction-Diffusive Reflectance Infrared Fourier Transform Spectroscopy (XRD-DRIFTS) investigations during Fischer-Tropsch synthesis over supported catalysts, yielded a correlation between catalyst structure and surface and catalytic properties. A paper entitled "Development of an Innovative XRD-DRIFTS Prototype Allowing Operando Characterizations during Fischer-Tropsch Synthesis over Cobalt-Based Catalysts Under Representative Conditions" by J. Scalbert, I. Clémençon, C. Legens, F. Diehl, D. Decottignies and S. Maury summarising this work is presented in this OGST dossier.

A role for large-scale research facilities, such as the European Synchrotron Radiation Facility (ESRF) was also presented, especially for detailed characterization of nano- and microstructured materials (i.e. for drug discoveries). A paper from J.M. Hudspeth, K.O. Kvashnina, S.A.J. Kimber and E.P. Mitchell discussing this subject entitled "Synchrotron X-Ray Scattering as a Tool for Characterising Catalysts on Multiple Length Scales" is included in this dossier.

Session 2 clearly showed the needs for both the characterization of complex materials at different scales, from the atomic, through nano-, micro- and meso-scopic levels, and the development of innovative instrumental tools to support such characterization.

Session 3 considered "High Throughput Experimentation (HTE) to Intensify the Discovery, Characterization and Evaluation of Materials".

The session included the description of a substantial number of HTE technologies. In this NextLab dossier, a paper entitled "High Throughput Experimentation (HTE) Directed to the Discovery, Characterization and Evaluation of Materials" by J.M. Newsam takes a strategic view of the development and application of HTE techniques across a broad spectrum of chemicals, materials and earth sciences, energy, catalysis, formulations and biotechnology fields. A few examples are the use of robotic systems for catalyst synthesis, and parallelized slug flow or stirred reactors for catalyst performance assessment. In the paper of this dossier entitled "The Use of Original Structure-Directing Agents for the Synthesis of EMC-1 Zeolite" by T.J. Daou, J. Dhainaut, A. Chappaz, N. Bats, B. Harbuzaru, H. Chaumeil, A. Defoin, L. Rouleau and J. Patarin, HTE synthesis of FAU- and EMT-type zeolites using novel templates designed by molecular modeling are detailed.

The HTE field was also illustrated by descriptions and displays of various advanced equipment suppliers and platforms (Avantium, REALCAT, SPACIM, etc.) to enable accelerated development of new catalysts, extending even to hybrid systems and biocatalytic processes. In this issue, S. Paul, S. Heyte, B. Katryniok, C. Garcia-Sancho, P. Maireles-Torres and F. Dumeignil present the platform REALCAT in their paper entitled "REALCAT: A New Platform to Bring Catalysis to the Lightspeed".

The session communications, and the discussions following, underlined that the use of HTE platforms for new catalyst RDD requires not only new instrumentation, but also substantial qualified human resources (engineers, scientists, technicians, informaticists and so on) able to manage large numbers of experiments, without ignoring safety and confidentiality considerations.

Session 4 addressed "Numerical and Experimental Tools to Process Scale-Up".

The session considered experimentation tools for understanding and designing heterogeneous catalysts systems, such as the Temporal Analysis of Products (TAP) approach, and Computational 
Fluid Dynamics (CFD) simulations for process scale-up. It was evident that there is a need for these kind of tools for 'process intensification'. An example of an industry-driven platform for knowledge and technology transfer in process intensification is given in this dossier by C. Gourdon, S. Elgue and L. Prat in their paper "What are the Needs for Process Intensification?".

A good opportunity to develop greener chemical processes may be presented by considering "novel process windows", such as engineering with microstructured equipment a process to operate safely at high pressures, at high temperatures, within explosive regimes, using green solvents, or leading to new chemical paths and transformations.

The effective and combined use of experimental and numerical tools in streamlining process scale-up was illustrated by $\mathrm{H}_{2}$ purification with Pressure Swing Adsorption (PSA) equipment using a special adsorbent, by a dynamic transient approach to study and optimize three-phase reactors, and by the use of CFD as a laboratory tool for planning experiments and for setting operating conditions without the need for measurements of fluid flows in a reactor.

The material presented and the discussions which followed the formal presentations clearly underlined the need for still further improved numerical and experimental tools to facilitate process scale-up for the "factory of the future". In seeking optimal efficiency in our experimentation, a clear conclusion was that experiment and simulation are quite complementary.

Session 5 covered "New Analytical Tools for Process Monitoring".

The session emphasized that Process Analytical Technology (PAT) with in situ analysis is at the "heart of the process". It is clear that new analytical tools and new approaches to product and process characterization are allowing both better process optimization, and improved process control.

Improvements have been impressive in various analytical techniques such as Raman and Infra-Red (IR) spectroscopy, Gas Chromatography (GC), High Performance Liquid Chromatography (HPLC), Nuclear Magnetic Resonance (NMR), Mass Spectrometry (MS), and Ultra Violet - Visible (UV-VIS) spectroscopy.

In parallel, microfluidic devices as analytical tools and miniaturized silicon MicroElectro Mechanical Systems (MEMS) chromatographic columns for oil field applications have been developed.

But, the set of presentations in the session underlines that no single analytical technique can allow a full description of a process, ensuring the need for a range of techniques and for an optimal use of the data that they are each capable of yielding.

Lastly, the final session, Session 6, appropriately took a forward-looking view, under the title "The Laboratory of the Future: Platforms, Projects and Collaborations-Sharing Visions".

The keynote lecture addressed by V. Hessel (Eindhoven Univ. of Technology, Netherlands) described a new approach to scale up a liquid conversion process to an industrial scale based on a modular compact container plant. Up to now, process intensification has largely meant process innovation through designing either new operating modes for existing equipment or novel equipment that permits new production methods and scales (such as micro structured reactors). More expansively, though, looking forward can we imagine new processes and then design exchangers, mixers, reactors etc. "to produce much more and better while using much less".

Moreover, in considering process intensification, a key for economic success today is a reduction in time-to-market, a reduced lead time in progressing innovation from the laboratory to the commercial production scale. The keynote lecture showed that the modular plant concept, using standardized compact modules, might reduce this time-to market by some $50 \%$.

The final conference session wrapped up with a discussion amongst a panel chaired by J.-C. Charpentier (LRGP/CNRS/ENSIC, Université de Lorraine) and comprising H. Cauffriez (IFPEN), E. Lecomte Norrant (UCB PHARMA, Belgium), P. Deschriver (SOLVAY, LOF, CNRS, Université de Bordeaux, France), F. Dumeignil (REALCAT, Université de Lille, France), E. Larrey (IDEEL factory, Lyon, France), J.M. Newsam (TIOGA Research, USA) and S. Jullian (MESR, France). 
Points developed throughout the NextLab 2014 meeting and articulated by the panel were wideranging:

- to create the concept of the laboratory of the future, find inspiration in real life (observation, art, market, etc.). Life should drive creation. Find research subjects from the market;

- the laboratory of the future: two complementary viewpoints:

$\circ$ the incremental lab (research, quality, manufacturing, etc.) to provide answers and knowledge (i.e. Science is the object): modeling, size/time modification, in situ/operando, ab initio modeling, in silico experiments, etc.;

o the breakthrough lab (creativity, innovation) to provide inspiration (i.e. Science is the tool): Big Data (let the computer think), Design Thinking (Mixer experiment), Art and Science, Crowdfunding experiment, etc.;

- experimentation tools are expected to continue to undergo continuous improvement, yet no tool can be universal and optimal progress will derive from employing the most effective tool(s) in the most effective way(s);

- experiments conducted on a small scale, using minute amounts of products, reducing the environmental impact of laboratories and exposure of researchers (miniaturization);

- use the potential offered by computational chemistry, in silico experiments and modeling as standard tools for the chemist, reducing the need for expensive experimentation;

- all data will become accessible by simulation, and the distinction between simulation and experiment will become further blurred;

- the evolving "e-environment", encompassing scientific (social) networking, cloud-based computing and services, and collaborators will provide opportunities for major new efficiencies, even "crowd-researching";

- sustainability concerns can impact not only our research themes, but also our research modus operandi;

- economic dimensions should be factored early into our research and development thinking;

- future research agenda will require still more multidisciplinary approach(es), with combined contributions from a broad range of disciplines: the borders between biology, chemistry, physics, material science and mathematics will further blur;

- while technical and process advances might accelerate research, development and deployment, we also need to consider the best ways to gear our RDD processes towards innovation and, perhaps inspired by "nature-art-science-engineering intersections", devise approaches might trigger fresh creative impulses;

- a balance between the motivations for enabling open access to data and results, and those for sustaining a competitive edge at institutional, corporate or national levels needs to be considered;

- the laboratory of the future may be a unit composed of several expert laboratories, with different geographic locations, mobilized on the basis of the specific research requirements (chemical reaction, separation methods, purification, modeling, etc.);

- our future environment will comprise not only the laboratory of the future or the factory of the future, but a strong connection even a shared vision between them.

The NextLab 2014 conference was organized by IFP Energies nouvelles under the 'Les Rencontres Scientifiques d'IFP Energies nouvelles' program and under the aegis of the French "Académie des Sciences". The conference was made possible thanks to the engagement of a number of leading scientists and with the generous support of industrial sponsors.

The formal oral and poster presentations at the NextLab 2014 conference itself, and the peerreviewed written contributions gathered in this dossier of OGST, necessarily convey work already completed, even if only quite recently. As Eric Heintzé noted, "These new research approaches based on innovative techniques, High Throughput Experimentation (HTE) methodologies and intensified tools, will anticipate the lab of tomorrow and will contribute to build the factory of the future". 


\title{
Éditorial
}

\section{VERS LE LABORATOIRE DU FUTUR POUR CONSTRUIRE L'USINE DU FUTUR}

\author{
V. Santos-Moreau', J.M. Newsam ${ }^{2}$ and J.-C. Charpentier ${ }^{3}$ \\ ${ }^{1}$ IFP Energies nouvelles, France \\ 2 TIOGA Research, USA \\ ${ }^{3}$ LRGP/CNRS/ENSIC, Université de Lorraine, France
}

Appartenant à une communauté scientifique concernée par les problèmes d'énergie, d'utilisation des ressources, de conversions chimiques et pétrochimiques, de rejets environnementaux et problèmes associés, nous sommes placés à l'avant-garde de défis scientifiques comportant un impact sociétal majeur. Nous ne pouvons plus nous offrir le luxe d'être motivés par simple curiosité ou compétition. Au contraire, nos préoccupations sont mises sous pression par les phénomènes urgents concernant la globalisation, le développement durable et les demandes pressantes d'innovation technologique. Mais, tel que présenté avec une recherche urgente et de plus bien décrite et avec un besoin de développement, comment peut-on être plus efficace, plus effectif, et finalement plus couronné de succès ? C'était la question posée par le thème du congrès NextLab 2014 qui a réuni des scientifiques et ingénieurs de 14 pays différents sur le site d'IFP Energies nouvelles à Rueil-Malmaison (France) du 2 au 4 Avril 2014.

Dans son discours d'ouverture, Eric Heintzé, directeur scientifique d'IFPEN, a insisté sur le but du congrès NextLab 2014 comme étant de " réunir différents acteurs, académiques et industriels, afin qu'ils partagent leurs expériences et leurs visions d'avenir sur le sujet du laboratoire du futur intégrant l'innovation ». Il a anticipé les présentations et «les débats constructifs 》 sur «les nouveaux outils porteurs, sur les méthodologies et sur les techniques à développer pour passer des échelles laboratoire aux échelles pilote puis aux échelles du procédé afin d'améliorer la connaissance et les progrès scientifiques et pour soutenir les activités d'innovation concernant les produits et les procédés ».

Le congrès était volontairement structuré pour attirer l'attention de façon progressive sur les phases-clés en Recherche, en Développement et en Déploiement (RDD), en insistant pour chacune de ces phases sur l'approche innovation.

La Session 1 a concerné "Les nouveaux outils expérimentaux et de simulation pour la conception, la synthèse et la formulation de matériaux ».

Cette session a mis en exergue d'abord l'utilisation de la modélisation moléculaire et des expériences in silico pour comprendre les phénomènes fondamentaux et pour accéder à des propriétés physiques autrement inaccessibles comme des propriétés de transport de matière et chaleur, certaines propriétés mécaniques, ou des propriétés redox. Des travaux de X. Rozanska, P. Ungerer, B. Leblanc, P. Saxe et E. Wimmer portant sur des simulations moléculaires atomistiques pour la détermination des propriétés physico-chimiques de différentes substances dans le contexte de la réglementation EU-REACH sont présentés dans le papier de ce dossier OGST intitulé «Simulations atomistiques automatiques et systématiques dans l'environnement logiciel de MedeA ${ }^{\circledR}$ : Application à EU-REACH». 
Ensuite la session a porté sur des approches pour produire de nouveaux résultats expérimentaux bien au-delà des possibilités des technologies courantes, comme les criblages à hauts débits (High Throughput Screening, HTS) des molécules tels les solvants ou d'autres matériaux pour une application industrielle précise.

Une des questions clés de cette session était « est-ce que les expériences moléculaires in silico sont aujourd'hui adaptées comme base de conception de produits et de procédés ? ». La réponse est encore clairement « Non ». Le laboratoire du futur devra nécessairement combiner de façon complémentaire des expériences réelles et virtuelles pour une conception plus efficace et sécurisée des procédés et produits et ce, en utilisant une approche multi-échelle.

La Session 2 a porté sur «Les outils et méthodes innovantes pour évaluer et caractériser des matériaux ».

Cette session a mis en évidence l'importance de l'utilisation d'outils de microfluidique, d'outils millifluidiques non conventionnels et plus généralement l'utilisation d'outils innovants pour la durabilité du développement de la chimie et des procédés, et l'obtention des données cinétiques pour les procédés chimiques. Ce thème a été illustré par l'utilisation d'outils thermographiques in situ et infrarouges pour la caractérisation du comportement du catalyseur pendant la réaction. Des observations résolues spatialement in situ ont permis de suivre le comportement d'un lit de catalyseur dans les conditions réactionnelles. Des expériences Operando XRD-DRIFTS (X-Ray Diffraction-Diffusive Reflectance Infrared Fourier Transform Spectroscopy) menées pendant une synthèse Fischer-Tropsch avec catalyseur supporté ont conduit à une relation entre la structure et la surface du catalyseur et ses propriétés catalytiques. Un article de J. Scalbert, I. Clémençon, C. Legens, F. Diehl, D. Decottignies et S. Maury intitulé « Développement d'un prototype DRX-DRIFTS innovant permettant des caractérisations operando de catalyseurs à base de cobalt pendant la synthèse de Fischer-Tropsch en conditions représentatives » résumant ces travaux est présenté dans ce dossier d'OGST.

De plus, le rôle d'équipements de recherche de grande échelle d'étude comme l'European Synchrotron Radiation Facility (ESRF) a également été présenté, tout spécialement pour des caractérisations fines de matériaux nano et micro structurés (i.e. pour la découverte de nouveaux principes actifs). L'article de J.M. Hudspeth, K.O. Kvashnina, S.A.J. Kimber et E.P. Mitchell intitulé « La diffusion des rayons $X$ synchrotron : un outil pour la caractérisation des catalyseurs sur les multiples échelles de longueur » résume dans ce dossier les principales avancées dans ce sujet.

La session 2 a clairement montré les besoins à la fois de caractérisation des matériaux complexes aux différentes échelles, atomiques, nano, micro et méso, et le développement d'instruments innovants pour obtenir de telles caractérisations.

La Session 3 a été dédiée à "L'expérimentation à hauts débits (EHD ou HTE - HighThroughput Experimentation) pour intensifier la découverte, la caractérisation et l'évaluation des matériaux ».

La session a proposé la description d'un grand nombre de technologies « HTE » orientées sur la découverte, caractérisation et évaluation des matériaux. Dans ce dossier, un article intitulé "Expérimentation à haut débit pour la découverte, la caractérisation et l'évaluation des matériaux » de J.M. Newsam, présente une vision stratégique du développement et application de technologies EHD dans différents domaines : chimie, science de la terre et des matériaux, énergie, catalyse, biotechnologie, etc.

Des exemples ont concerné entre autres l'utilisation de systèmes robotisés pour la synthèse catalytique et l'utilisation de microréacteurs montés en parallèle, avec par exemple des écoulements de Taylor (slug flow) en continu ou des réacteurs agités, pour l'estimation des performances cinétiques dans le cas de réactions chimiques polyphasiques rapides. Dans l'article de ce dossier intitulé «L'utilisation d'agents structuraux originaux pour la synthèse de zéolithe EMC-1 » de T.J. Daou, J. Dhainaut, A. Chappaz, N. Bats, B. Harbuzaru, H. Chaumeil, A. Defoin, L. Rouleau et J. Patarin, la synthèse EHD de zéolites FAU et EMT 
en utilisant une approche "stérique » par modélisation moléculaire pour concevoir des agents structurants qui s'adaptent bien à la porosité de la charpente minérale est décrite.

Le thème de la session a été aussi illustré par la description et la présentation d'équipements et de plate-formes en pointe (comme Avantium, REALCAT, SPACIM) proposés pour un développement accéléré de nouveaux catalyseurs, y compris ceux concernant les systèmes catalytiques hybrides (chimiques et biochimiques) et les procédés biocatalytiques. Ainsi dans l'article intitulé « REALCAT : une nouvelle plate-forme pour mener la catalyse à la vitesse de la lumière » de S. Paul, S. Heyte, B. Katryniok, C. Garcia-Sancho, P. Maireles-Torres et F. Dumeignil, la plateforme REALCAT est présentée.

La session et les discussions pendant les présentations ont souligné que l'utilisation des plateformes d'expérimentation à hauts débits pour la recherche, le développement et le déploiement de nouveaux catalyseurs requiert non seulement une instrumentation sophistiquée, mais aussi des ressources humaines importantes (ingénieurs, scientifiques, techniciens, informaticiens, etc.) capables d'être confrontées avec un très grand nombre d'expériences, tout en prenant en compte également les considérations de sécurité et de confidentialité.

La Session 4 a concerné «Les outils numériques et expérimentaux pour l'extrapolation des procédés ».

La session a présenté des outils d'expérimentation pour la compréhension et la conception de systèmes catalytiques hétérogènes comme l'outil (TAP) (Temporal Analysis of Products) et des outils de simulation numérique «CFD » (Mécanique des Fluides Numérique, Computational Fluid Dynamics) pour l'extrapolation de procédés. Par ailleurs, il est apparu de façon évidente des besoins de ces types d'outils et d'équipements pour "l'intensification des procédés ». Un exemple d'une plateforme pilotée par l'industrie pour la R\&D et pour le transfert de technologie présenté dans l'article intitulé "Quels besoins pour intensifier un procédé ? " par C. Gourdon, S. Elgue et L. Prat, aborde ce sujet.

Il a aussi été mentionné qu'une grande opportunité de développer des procédés chimiques plus durables (verts) était offerte en considérant la notion de « nouvelle gamme de fonctionnement de procédé (novel process window) » pour concevoir des procédés fonctionnant à très hautes pressions, très hautes températures, dans des conditions explosives, pour concevoir des procédés utilisant des solvants verts ou pour obtenir de nouvelles voies de transformations chimiques.

Des illustrations ont porté sur l'utilisation effective et combinée d'outils expérimentaux et numériques pour l'extrapolation de procédés en cours d'exploitation comme la purification de $\mathrm{H}_{2}$ avec un équipement de type PSA (Pressure Swing Adsorption), ou sur le fonctionnement en régime transitoire des réacteurs triphasiques pour étudier et optimiser leur rendements ou bien encore sur l'utilisation de la CFD comme outil de laboratoire pour planifier les expériences et pour délimiter les conditions opératoires sans avoir recours au préalable à des expériences concernant les écoulements de fluides dans les réacteurs.

Les présentations lors de la session et les discussions qui ont suivi ont clairement mis en évidence le besoin encore requis d'améliorer les outils numériques et expérimentaux nécessaires pour faciliter l'extrapolation dans la conception de «l'usine du futur ». Et si l'on cherche une optimisation efficace dans les expérimentations, il est clair que la conclusion est qu'expérimentation et simulation sont complémentaires.

La Session 5 a porté ensuite sur «Les nouveaux outils pour la conduite des procédés ».

La session a mis en exergue le fait que les technologies d'analyse des procédés "PAT» (Process Analytical Technologies) avec des analyses in situ étaient « au cœur du procédé ». Il est clair que les nouveaux outils analytiques et les nouvelles approches de caractérisation des produits et procédés fournissent à la fois une meilleure optimisation de procédés et un contrôle amélioré du procédé.

En effet des progrès impressionnants ont été effectués dans des techniques analytiques variées comme la spectroscopie Raman, la spectroscopie infrarouge, la chromatographie en phase gazeuse, la chromatographie liquide haute performance (HPLC), la résonance magnétique 
nucléaire (NMR), la spectrométrie de masse (MS) et la spectroscopie ultraviolet - visible (UVVIS). Parallèlement, en tant qu'outils analytiques, des équipements microfluidiques et des colonnes chromatographiques comportant des systèmes microélectromécaniques (MEMS, MicroElectroMechanical Systems) à base de silicium miniaturisés ont été développés par exemple pour des applications sur champs pétroliers.

Néanmoins, l'ensemble des présentations de la session a souligné qu'il n'existe pas aujourd'hui une technique analytique unique qui permette d'obtenir une description complète d'un procédé, ce qui assure le besoin d'avoir recours à d'autres techniques et d'utiliser de façon optimale les résultats qu'elles sont chacune capables de fournir.

La Session 6 finale a apporté de façon appropriée une vision d'avenir, sur «le laboratoire $d u$ futur : plateforme, projets et collaborations, partage de visions $»$.

La conférence d'introduction de la session qui a été présentée par V. Hessel (Eindhoven Univ. of Technology) a proposé une nouvelle approche pour extrapoler un procédé de conversion en phase liquide basée sur la notion d'usine à containeurs modulaires compacts.

Jusqu'à présent l'intensification des procédés a grandement signifié innovation de procédés avec la conception de nouveaux modes opératoires des équipements existants ou la conception de nouveaux équipements qui permettent de nouvelles méthodes et échelles de production (ex. réacteurs microstructurés). Le but était et est clairement d'imaginer de nouveaux procédés et de concevoir ensuite des échangeurs, des mélangeurs, des réacteurs, etc. pour « produire plus et mieux en utilisant beaucoup moins ».

De plus, en ce qui concerne l'intensification des procédés, la clé aujourd'hui pour un succès économique est la réduction du temps d'arrivée sur le marché (time-to-market), c'est-à-dire la réduction du temps d'innovation nécessaire au passage du laboratoire à la production commerciale. Et la conférence d'introduction de la session a montré que le concept d'usine modulaire avec des modules compacts standardisés pourrait réduire de $50 \%$ le temps d'arrivée sur le marché.

La session finale s'est conclue par une table ronde animée par J.-C. Charpentier (LRGP/CNRS/ ENSIC, Université de Lorraine, France) et comprenant H. Cauffriez (IFPEN), E. Lecomte Norrant (UCB PHARMA, Belgique), P. Deschriver (SOLVAY, LOF, CNRS, Université de Bordeaux, France), F. Dumeignil (REALCAT, Université de Lille, France), E. Larrey (IDEEL FACTORY, Lyon, France), J.M. Newsam (TIOGA Research, USA) and S. Jullian (MESR, France).

Les sujets développés pendant le congrès NextLab 2014 et discutés pendant la table ronde couvrent de nombreux thèmes et apportent de nombreuses conclusions sur le fait que :

- pour créer le laboratoire du futur, il faut trouver de l'inspiration dans la vie de tous les jours (observation, art, marché, etc.). La vie doit conduire la création et les sujets de recherche doivent être issus des besoins du marché ;

- pour le laboratoire du futur il y a deux visions complémentaires :

$\circ$ un laboratoire incrémental (recherche, qualité, etc.) qui permet de fournir des informations et connaissance (i.e. la science est l'objet) : modélisation, in situ/operando, modélisation ab initio, expérimentation in silico, etc. ;

○ un laboratoire en rupture (créativité, innovation) pour créer de l'inspiration (i.e. la science est l'outil) : Big Data (« laisser l'ordinateur penser »), Design Thinking, art et science, etc. ;

- les outils expérimentaux sont censés continuer à se développer avec des améliorations continues, aucun outil expérimental n'étant à ce jour universel ; les grands progrès découleront de l'utilisation des outils les plus efficaces et de la manière la plus efficace ;

- la tendance sera d'avoir des expérimentations à petite échelle, en utilisant de faibles quantités de produits, en réduisant l'impact environnemental des laboratoires et l'exposition des chercheurs;

- utiliser pleinement la chimie informatique, les expérimentations in silico et la modélisation comme outils standard pour la réduction du nombre d'expériences coûteuses. Tous les résultats deviendront accessibles par simulation numérique et la distinction entre simulation et expérimentation s'estompera ; 
- l'évolution du e-environnement, le réseautage ambiant scientifique (social), la puissance informatique et les services associés, les collaborations vont fournir des opportunités pour de nouvelles efficacités majeures pour les investigations, incluant même une recherche de masse ;

- les considérations concernant le développement durable peuvent avoir un impact non seulement sur nos thèmes de recherche, mais aussi sur nos modus operandi de recherche ;

- les dimensions économiques devraient être prises en compte dès le début de nos démarches, à la fois dans nos activités de recherche et dans les façons de penser leur développement ;

- nos programmes futurs de recherches nécessiteront encore plus d'approches multidisciplinaires avec des contributions conjointes provenant d'une grande panoplie de disciplines : les frontières entre biologie, chimie, physique, science des matériaux, mathématique, etc. devront s'estomper ;

- bien que les avancées dans les domaines de la technique et des procédés puissent accélérer la recherche, le développement et la mise sur le marché des produits, il faut considérer la meilleure façon possible d'orienter les processus de RDD vers l'innovation. Les produits peuvent être inspirés par les recouvrements nature-art-science-ingénierie et nos dispositions imaginatives pourraient déclencher des nouvelles impulsions créatives ;

- il faut considérer un équilibre entre les motivations pour un accès ouvert aux données et aux résultats, et les motivations pour maintenir un côté compétitif aux niveaux institutionnel, de l'entreprise ou national ;

- le laboratoire du futur pourra être composé de plusieurs laboratoires experts en réseau avec différentes localisations géographiques selon les différents besoins de recherche (réaction, séparation, purification, modélisation, etc.) ;

- notre environnement futur comprendra non seulement le laboratoire du futur ou l'usine du futur, mais une forte connexion et même une vision partagée entre les deux.

Le congrès NextLab 2014 a été organisé par IFP Energies nouvelles dans le cadre du programme «Les Rencontres Scientifiques d'IFP Energies nouvelles » et sous l'égide de l'Académie des Sciences Française. Ce congrès a été rendu possible grâce à l'engagement d'un grand nombre de scientifiques renommés et avec le support financier de généreux commanditaires industriels.

Les présentations orales et sous forme d'affiches pendant le congrès et les contributions qui sont rassemblées dans ce dossier d'OGST proposent des travaux qui ont déjà été effectués et pour certains d'entre eux très récemment. Et il faut souligner, comme l'a mentionné Eric Heintzé, que « ces nouvelles approches de recherche fondées sur des techniques innovatrices, sur des méthodologies de type HTE et sur des outils intensifiés, anticiperont le laboratoire de demain et contribueront à la construction de l'usine du futur ». 